\title{
10 \\ The Uncomfortable Wars of the 1990s
}

\author{
John Nagl and Octavian Manea
}

\section{The Spirit of the 1990s}

After the shock and awe of Operation Desert Storm, in which one of us participated directly, the remainder of the 1990s confronted the West with a series of instabilities of a different nature. The post-Cold War security environment reflected less the typical challenges generated by strong powers that, for centuries, were at the core of the main international rivalries, and more a world of challenges produced by weak and failed states. Where the problems of the short twentieth century (1914-1991) were caused by states that were too strong and wanted to expand their borders, the problems of the decades that followed would be caused by states that were too weak to govern within their own borders. It was a world shaped not by the classical balance of power, as in the past, but increasingly by a balance of weakness. The new reality produced two immediate consequences. On one side, there was a shifting away from the paradigm of symmetric state-to-state conflict toward intrastate wars, where religious and ethnic identities, as well as communities and groups, were the key 
variables shaping the violence cycles. ${ }^{1}$ Sectarian and ethnic security dilemmas, well orchestrated by interested elites, swamped the public space by amplifying group fears. It was the moment of coldblooded opportunists such as Slobodan Milosevic, Ratko Mladic, and Mohamed Farah Aideed, who understood human nature and knew that the instinct of resorting to violence 'has been deeply seated in our stock for hundreds of thousands of years'. ${ }^{2}$

They just needed to nurture the right conditions and mobilise those fears against the right target for their own benefit. As Robert $\mathrm{O}^{\prime}$ Neill put it:

The leaders of religious, ethnic and immigrant communities, and of political parties or factions thereof, will continue to draw on this source of influence and exploit it both for indirect leverage in bargaining and for direct effect in conflict when all else seems likely to fail. Thus it is more at this level than that of nations that we must aim our policies in post-Cold War Europe. ${ }^{3}$

On the other side, the societal dimension of modern warfare took primacy of place. To win back its legitimacy, 'the government must address contentious, long ignored, but popular issues tied to key facets of national life (socio-political, economic, educational, juridical)' ${ }^{4}$ In fact, it was this societal dimension that endangered Europe the most, particularly the

avalanche of chaos falling on the West from the Centre, East and South ... The causes of such dangers lie primarily in the weak, defective political structures of most of the states on Europe's southern and eastern flank ... In many of them corruption and maladministration are rife. Several are disintegrating. ${ }^{5}$

1 Snyder, Jack (2007) 'International Sources of Interstate and Intrastate War', in Chester A. Crocker, Fen Osler Hampson and Pamela Aall (eds) Leashing the Dogs of War: Conflict Management in a Divided World, Washington: United States Institute of Peace Press, p. 19.

2 O'Neill, Robert (1998) 'Europe and the Wider World: The Security Challenge', in Ken Booth (ed.) Statecraft And Security. The Cold War and Beyond, New York: Cambridge University Press, p. 198.

3 Ibid.

4 Galvin, John R. (1986) ‘Uncomfortable Wars: Toward a New Paradigm', Parameters 26(4), p. 6. 5 O'Neill, Robert (1998) 'Europe and the Wider World: The Security Challenge', in Ken Booth (ed.) Statecraft And Security. The Cold War and Beyond, New York: Cambridge University Press, pp. 198-9. 
This structural reality would ultimately trigger the Western interventionism in former Yugoslavia, in Bosnia (1995) and Kosovo (1999), but it was also instrumental in laying the ground for successive NATO and EU enlargements to the east.

Unfortunately, Western military establishments were deeply entrenched in the interstate paradigm and resistant to move beyond their organisational culture. ${ }^{6}$ But the new societal dimensions of warfare - requiring roles as diverse as peacekeeping, providing humanitarian assistance, disaster relief, post-conflict reconstruction, and counterinsurgency - were not amendable to solution by what General Anthony Zinni called 'a Cold-War era military machine'. As Robert O'Neill put it:

Gone are the days when NATO armies could plan around a single mission ... [T] hey still have to be able to fight, of course, but they have to be able to do many other things as well, from re-building shattered cities to supervising elections ... [T] heir inherited Cold War skills, structures and approaches can sometimes be irrelevant or even counterproductive. Future development has to address responsibilities that will be much more intrinsically political in nature, such as the promotion of democratisation, support for human rights, policing of international law and the apprehension of war criminals. ${ }^{8}$

The struggle between entrenched organisational culture and new strategic requirements became the hallmark of the civil-military gap that defined the debates inside the Clinton Administration during the 1990s, and marked the first generation of the next century.

6 Priest, Dana (2004) The Mission: Waging War and Keeping Peace with America's Military, New York: W.W. Norton \& Company, p. 26.

7 Zinni, Anthony C. (2001) 'A Military for the Twenty-First Century: Lessons from the Recent Past', Strategic Forum 181. Available at: www.au.af.mil/au/awc/awcgate/ndu/sf181.htm.

8 O'Neill, Robert (1997) 'The Remaking of Modern Armies Post Cold War', in Peter Dennis and Grey Jeffrey (eds) The Second Fifty Years: The Australian Army 1947-1997, Canberra: Australian Defence Force Academy, pp. 3-4. 


\section{Black Hawk Down Meets Assertive Multilateralism}

Bill Clinton did not run for the Presidency on his foreign policy credentials; to the contrary, 'it's the economy, stupid' was the focus of his campaign. The theme resonated with the American public, who were reluctant to support a muscular role on the global stage after victory in the Cold War. Richard Holbrooke, one of the core members of the Clinton team, captured well the public mood:

In the decade before 9/11, Americans had turned away from the outside world after 60 years of continuous and expensive international involvement, from Pearl Harbor to the disintegration of the Soviet Union at the end of 1991. Americans were proud, of course, that their sacrifices had succeeded in defeating both fascism and communism during that long period, but they were exhausted and ready to turn inward. ${ }^{9}$

It was the end of history, the time of peace dividends, not of overseas interventions in non-strategic internal conflicts. ${ }^{10}$ The only nation building to be done was here at home; ${ }^{11}$ 'In the glow of having won the cold war, Americans felt that they could rest on the assurance of the security its superpower status provided. ${ }^{12}$

The US mission in Somalia evolved from a purely humanitarian one to fighting local militias and hunting rogue leaders almost without Washington noticing the change. ${ }^{13}$ The end result was the 'Black Hawk Down' moment on 3 October 1993, when 18 Americans were killed on the streets of Mogadishu while the image of angry mobs celebrating shocked America and the world. The net effect was an increased reluctance in congress to engage internationally, and public opinion decided to stay away from foreign entanglements. For President

9 Chollet, Derek and Samantha Powers (eds) (2011) The Unquiet American: Richard Holbrooke in the World, Philadelphia: Public Affairs, p. 227.

10 Soderberg, Nancy (2005) The Superpower Myth: The Use And Misuse of American Might, New Jersey: John Wiley \& Sons, p. 18.

11 Chollet, Derek and James Goldgeier (2008) America Between the Wars: From 11/9 to 9/11, New York: Public Affairs, p. 57.

12 Soderberg, Nancy (2005) The Superpower Myth: The Use And Misuse of American Might, New Jersey: John Wiley \& Sons, p. 20.

13 Chollet, Derek and James Goldgeier (2008) America Between the Wars: From 11/9 to 9/11, New York: Public Affairs, p. 93. 
Clinton, this was an essential learning moment: 'I know we can intervene in these little countries with great ease and the first seventytwo hours go really well. But I am concerned what happens after that. I don't want to do Haiti unless I'm confident there's a plan for the day after. ${ }^{\prime 14}$ As Robert $\mathrm{O}^{\prime}$ Neill would emphasise:

There has always been a high correlation between success in war and ability to achieve a clean termination - although this has not been recognised widely until recently. We now acknowledge the importance of the exit strategy. Ideas on what makes a successful conclusion and how to disengage after achieving it need to be thought through before beginning a war or intervention, and not after it has begun to go awry. ${ }^{15}$

The direct outcome of this heightened sensitivity toward an exit strategy was Presidential Decision Directive 25. Adopted in May 1994, it focused on clarifying the criteria for US participation in multilateral peace operations. The document emphasised the need for clearly defined objectives, sufficient forces, and realistic criteria for ending American participation in overseas adventures. It was very much a product of its times, with Somalia and Vietnam traumas and the Powell Doctrine being the main drivers. ${ }^{16}$ In fact, the combined legacies of the two perceived quagmires would greatly impact the American use of force in the 1990s, with 'memories of Mogadishu which hung over our deliberations like a dark cloud; and Vietnam, which lay further back, in the inner recesses of our minds', as Richard Holbrooke would later say about Dayton. ${ }^{17}$

There were two broad camps that shaped the debate inside the White House, related to the question of how to use unipolar power to respond to the challenges of the new security environment. On one side there was a generation shaped by a certain reading of the Vietnam quagmire. Against this formative experience, an entire generation of

14 Daalder, Ivo H. and I. M. Destler (2009) In the Shadow of the Oval Office: Profiles of the National Security Advisers and the Presidents they Served: From JFK to George W. Bush, New York: Simon \& Schuster, p. 232.

15 O'Neill, Robert (1999) 'Success and Failure in War in the Twentieth Century', paper at the Second Symposium of War and Peace in the Twenty-First Century: Reflections upon the Century of War, Tokyo, October 7-8, 1999, p. 117. Available at: www.nids.go.jp/english/event/ symposium/pdf/1999/sympo_e1999_3.pdf.

16 Davidson, Janine (2010) Lifting the Fog of Peace: How Americans Learned to Fight Modern War, Ann Arbor: University of Michigan Press, p. 84.

17 Ibid., p. 92. 
officers became the guardians (to use the term of the historian Brian McAllister Linn) of a proper use of force, of a betrayed way of war that should not have been distracted by nation-building. For them, 'Vietnam provided a collective identity'18 symbolising the essence of all wrongs and of how not to fight a war. For General Colin Powell, it reflected a 'belief in using all the force necessary to achieve the kind of decisive and successful result that we had achieved in the invasion of Panama and in Operation Desert Storm'.${ }^{19}$ It also expressed a promise: 'Many of my generation, the career captains, majors, and lieutenant colonels seasoned in that war, vowed that when our turn came to call the shots, we would not quietly acquiesce in halfhearted warfare for half-baked reasons that the American people could not understand or support', as Powell would write in his memoirs. ${ }^{20}$ In this interpretation, incrementalism, the use of force in small progressive doses, was a recipe for disaster. It was the equivalent of 'not being allowed to fight to win'.$^{21}$ Instead, they favoured an overwhelming force paradigm, or 'the bully's way of going to war', ${ }^{22}$ but only in circumstances that displayed realistic achievable political outcomes, clear exit strategies, and in the service of direct US vital national interests. The Weinberger-Powell doctrine reflected 'a utilitarian realistic yardstick', ${ }^{23}$ an 'intervention test', ${ }^{24}$ a set of guidelines that should be applied any time America would go to war. There were many inside the Clinton administration for whom the Powell Doctrine was raising questions - 'the kind of which we should have asked in Vietnam' as Tony Lake, Clinton's first national security advisor,

18 Linn, Brian McAllister (2009) The Echo of Battle: The Army's Way of War, Cambridge: Harvard University Press, p. 195.

19 Powell, Colin with Tony Koltz (2012) It Worked For Me: In Life and Leadership, ebook edition, New York: HarperCollins, loc. 2634.

20 Chollet, Derek and Samantha Powers (eds) (2011) The Unquiet American: Richard Holbrooke in the World, Philadelphia: Public Affairs, p. 214.

21 Davidson, Janine (2004), ‘Giving Peace a Chance: The Modern Military's Struggle Over Peace Operations', Small Wars and Insurgencies 15(2), p. 176.

22 Buley, Benjamin (2008) The New American Way of War: Military Culture and the Political Utility of Force, New York: Routledge, p. 67.

23 Handel, Michael I. (2001) Masters of War: Classical Strategic Thought, London: Frank Cass, p. 246 .

24 Smith, Rupert (2006) The Utility of Force: The Art of War in the Modern World, London: Penguin Books, p. 309. 
put it. ${ }^{25}$ From this perspective, the Bosnia and Somalia entanglements were simply a déjà vu of those specific political and military errors, a replay of the Vietnam War:

[W] henever the military had a clear set of objectives ... as in Panama, the Philippine coup, and Desert Storm, the result has been a success. When the nation's policy was murky or nonexistent - the Bay of Pigs, Vietnam, creating a Marine presence in Lebanon - the result has been a disaster. In Bosnia, we were dealing with an ethnic tangle with roots reaching back a thousand years. ${ }^{26}$

In the 1990s, this reluctance to use force in outlier cases - especially in areas considered outside US vital interests - that didn't fit the very strict criteria developed by the Powell doctrine came to be described as Vietmalia syndrome. ${ }^{27}$ In practice, this described the collective aversion to both nation building and casualties' ${ }^{28}$ At a deeper level, it reflected a profound reluctance on behalf of the US military to deal with the societal dimension of warfare - the underlying domestic political roots of the new wars - that the trends and realities pushed towards it at the forefront of the post-Cold War world. In short, it was a policy meant to ensure that the military would only fight the comfortable, speedy wars that they wanted to fight, on their terms: 'win decisively, and come home swiftly with few casualties and to great public approval. ${ }^{29}$ It was also the embodiment of a specific organisational culture, one suited for the political imperatives of the industrial war paradigm - for Desert Storm-like operations, but not for wars amongst the people 'where the object is the will of the people, where the enemy is operating as guerillas, or where conditions of acceptable governance are to be created and maintained'. ${ }^{30}$

25 Interview with Anthony Lake (2002) Miller Center, University of Virginia. Available at: millercenter.org/oralhistory/interview/anthony-lake-2002.

26 Soderberg, Nancy (2005) The Superpower Myth: The Use And Misuse of American Might, New Jersey: John Wiley \& Sons, p. 23.

27 Chollet, Derek and Samantha Powers (eds) (2011) The Unquiet American: Richard Holbrooke In The World, Philadelphia: Public Affairs, p. 215.

28 Davidson, Janine (2010) Lifting the Fog of Peace: How Americans Learned to Fight Modern War, Ann Arbor: University of Michigan Press, p. 90.

29 Davidson, Janine (2013) 'Civil-Military Friction and Presidential Decision Making: Explaining the Broken Dialogue', Presidential Studies Quarterly 43(1), p. 143.

30 Smith, Rupert (2006) The Utility of Force: The Art of War in the Modern World, London: Penguin Books, p. 310. 
On the other side of the Clinton Administration, there was a group with a different mindset that had a much more nuanced interpretation of what the American role in the post-Cold War world should be. They believed in affirming US leadership and power, including through the limited use of America's military power, in the service of 'assertive multilateralism'. ${ }^{31}$ Their lessons were not Vietnam related, but reflected the legacies of Munich and the Holocaust as 'the benchmark horrors'32 of a previous interwar period that was shaped by the absence of America from the world stage. It was a generation of policy-makers with Wilsonian tones, for whom human rights, democracy, and liberal values should be at the core of US foreign policy. ${ }^{33}$ Its informal leader was Madeleine Albright, a refugee from Czechoslovakia and the hawk of the administration that was always pressing for stronger US action against repression, especially in Europe' ${ }^{34}$ What mattered most for them were the failures of past collective security organisations to act when international peace and security was threatened. From this perspective, the collapse of former Yugoslavia and its ripple effects (between 1991 and 1995 the death toll was close to a staggering 300,000 ) provided a textbook case: it was 'the greatest collective security failure of the West [in Europe] since the 1930s', ${ }^{35}$ and many in the Clinton Administration were determined not to let happen again. This resonated deeply with the personal experiences of both Albright and Holbrooke, for whom the past European tragedies of communism and Nazism were deeply ingrained in the background of their families. In Holbrooke's case, the sense of European history was even more amplified - both of his parents were refugees from Nazism, and his wife, Kati Marton, was a Jewish refugee from Hungary, a country left within the Iron Curtain's deadly embrace. ${ }^{36}$ At the same time, they were part of a generation that believed that past European tragedies

\footnotetext{
31 Chollet, Derek and James Goldgeier (2008) America Between the Wars: From 11/9 to 9/11, New York: Public Affairs, p. 69.

32 Ibid.

33 Ibid., p. 82.

34 Soderberg, Nancy (2005) The Superpower Myth: The Use And Misuse of American Might, New Jersey: John Wiley \& Sons, p. 15.

35 Chollet, Derek and James Goldgeier (2008) America Between the Wars: From 11/9 to 9/11, New York: Public Affairs, p. 269.

36 Chollet, Derek and Samantha Powers (eds) (2011) The Unquiet American: Richard Holbrooke in the World, Philadelphia: Public Affairs, p. 165.
} 
demonstrated that the maintenance of stability in Europe is a multilateral problem. There is no invisible hand to keep its nations from colliding with each other. If all interpretation of state behaviour is done on a unilateral basis by other states, suspicions and mistrust will accumulate. ${ }^{37}$

At the time, the philosophical gap between the two schools of thought came to be symbolised by the historical exchange between the riskaverse mindset of General Colin Powell (the Chairman of the Joint Chiefs of Staff), and Madeleine Albright (the US Ambassador at the UN) who famously asked: 'What's the point of having this superb military that you're always talking about if we can't use it?'38

A compromise was ultimately mediated, preparing the ground for the coercive diplomacy campaigns in Bosnia and Kosovo, the hallmarks of a new post-Cold War interventionism. It was a prudent embracing of those who advocated a humanitarian intervention doctrine, a combination between

those who bring a heartfelt passion to the issues but then an essential skepticism and moderation as they apply their minds to the issues. Because when you move from ideals to ideology you get in trouble. That was certainly the great lesson of Vietnam. ${ }^{39}$

Nobody will better sum up this compromise that captured the logic of the Clinton wars, than General Wesley Clark: 'if you line up international law, good diplomacy, and modern military power, you can achieve strategically decisive results without decisive force. ${ }^{\prime 40}$

Over time, the interpretation of threats that the instabilities in the Balkans posed to NATO and to US interests gradually changed. The new consensus reflected the conviction that, left unchecked, the spilling over effects could challenge regional stability in Europe: 'mindful of the fact that seen decades earlier, violence in the region had triggered a world war, Clinton recognised that Milosevic's

37 O'Neill, Robert (1998) 'Europe and the Wider World: The Security Challenge', in Ken Booth (ed.) Statecraft And Security. The Cold War and Beyond, New York: Cambridge University Press, p. 196.

38 Buley, Benjamin (2008) The New American Way of War: Military Culture and the Political Utility of Force, New York: Routledge, p. 80.

39 Interview with Anthony Lake (2002) Miller Center, University of Virginia. Available at: millercenter.org/oralhistory/interview/anthony-lake-2002.

40 Priest, Dana (2004) The Mission: Waging War and Keeping Peace with America's Military, New York: W.W. Norton \& Company, p. 258. 
dream of Greater Serbia and his campaign of ethnic cleansing could have grave consequences for the rest of Europe' ${ }^{41}$ For Tony Lake, the National Security Advisor in the first Clinton Administration, the danger was clear: 'the war in Bosnia could have sparked a wider conflagration in Europe, affecting some of America's NATO allies and many of the continent's new democracies. ${ }^{42}$ Imagining the result if the international community had not intervened:

$[T]$ he Serbs would have continued their offensive; more than a million and a half Kosovars would today be sitting in camps or starving in the hills with no hope of return; Milosevic would be strengthened; and in a region with many unresolved ethnic tensions, potential dictators would have learned the lesson that massive violence will draw no response from the international community. ${ }^{43}$

\section{A Syria avant la lettre at NATO's doorstep.}

In Bosnia and Kosovo, the core signature of the American way of war during the 1990s was the use of airpower and precision guided munitions (PGMs) to coerce and compel an adversary. In part, the choice was rooted in the risk-adverse mindset, or the body bags syndrome, displayed by the US military in campaigns that essentially were wars of choice that did not reflect American vital national interests (such as Lebanon or Somalia). On the other hand, there was a belief that in the post-Desert Storm age of PGMs, airpower could make a huge difference by providing a clean, surgical strike capability to be used in limited coercive diplomacy campaigns designed to compel the other side to change behaviour or negotiate. It captured the mindset of the senior civilian officials in the Clinton Administration - the so-called Surgical Strike School - who assumed a high degree of precision in the application of limited force, but also an ability to 'achieve limited political objectives' without escalating the effort. ${ }^{44}$ The major flaw of this approach was that it fundamentally ignored the human domain, those societal forces that make people tick and move communities

\footnotetext{
41 Soderberg, Nancy (2005) The Superpower Myth: The Use And Misuse of American Might, New Jersey: John Wiley \& Sons, p. 77.

42 Lake, Anthony (2000) Six Nightmares, New York: Hachette Book Group, p. 114.

43 Steinberg, James (1999) 'A Perfect Polemic: Blind to Reality on Kosovo', Foreign Affairs 78(6), pp. 128-33. Available at: www.foreignaffairs.com/articles/kosovo/1999-11-01/perfect-polemicblind-reality-kosovo.

44 Zenko, Micah (2010) Between Threats and War: U.S. Discrete Military Operations in the PostCold War World, Stanford: Stanford University Press, p. 24.
} 
at the grass-root level ('ethnic divisions, traditional relationships, ideology, religion, attitudes, nationalism, beliefs, family structure, customs, culture') while the core focus of the US military remained on 'machines, organization, equipment, maximizing firepower, reducing casualties, accurate employment of weapons on target'.$^{45}$ The combined outcome of the Powell-Weinberger Doctrine and the Surgical Strike School was an army unprepared for campaigns 'more politically complicated than Desert Storm ... Although the military knew how to win battles, it had no sense of how to use American power to achieve political objectives - to win wars. ${ }^{\prime 46}$

Arguably one of the most influential thinkers at the time was John Warden, an air force fighter pilot whose ideas about the use of airpower were instrumental in developing the Desert Storm's air campaign. He understood the enemy as a system, as a collection of multiple centres of gravity, of points 'where the enemy is most vulnerable and where an attack will have the best chance of being decisive'. ${ }^{47}$ The five rings ${ }^{48}$ that Warden listed - leadership, key industrial production, infrastructure, population, and fielded forces - would be at the forefront of the coercive acupuncture campaigns of the 1990s. For example, during Operation Deliberate Force in Bosnia (September 1995), NATO disrupted the ability of the Bosnian Serbs to move their forces around the battlefield by effectively destroying their communications network. ${ }^{49}$ The emphasis was on cutting the communication between 'the brain' and 'the muscles' - as Adrian R. Lewis later put it, 'the objective of operations was to destroy the system of nerves that transmitted orders from the brain to the muscles, severing the links between the decision makers and the fighting forces' ${ }^{50}$ But what added to the coercive leverage of NATO was the synergy effect achieved in conjunction with the ground offensives of the Muslim and Croat forces that threatened the balance of power on

45 Lewis, Adrian R. (2007) The American Culture of War: The History of U.S. Military Force from World War II to Operation Iraqi Freedom, New York: Routledge, p. 391.

46 Nagl, John (2014) Knife Fights: A Memoir of Modern War in Theory and Practice, New York: Penguin Books, p. 46.

47 Quoted in Kagan, Frederick W. (2006) Finding the Target: The Transformation of American Military Policy, New York: Encounter Books, p. 114.

48 Ibid., p. 121.

49 Ibid., p. 187.

50 Lewis, Adrian R. (2007) The American Culture of War: The History of U.S. Military Force from World War II to Operation Iraqi Freedom, New York: Routledge, p. 389. 
the battlefield. ${ }^{51}$ The altered context played directly into the Bosnian Serbs' fears of being dominated by competitive ethnicities, so rather than completely losing their defensive capacity, they decided to bargain and negotiate. ${ }^{52}$ For some in the Clinton Administration, the lesson was about the power of technology to compel an adversary to alter his behaviour:

Imagine you were a Bosnian Serb in the 1995, as US troops used electronic warfare to find and cripple your radar and anti-aircraft missiles, and then hit you with accurate long-range strikes against which you had no effective response. No wonder you'd have concluded you stood a better chance of survival at the negotiating table than on the battlefield. ${ }^{53}$

The Kosovo campaign was a much more complicated story. For Slobodan Milosevic and NATO, the symbolic stakes were much higher. Kosovo was the historical birthplace for the Serbian nation. NATO, an alliance in its 50s that year, couldn't let the bloodshed and the ethnic cleansing orchestrated by Milosevic to continue without impunity. Its entire relevance in the post-Cold War world as a collective security organisation would have been otherwise questioned. The use of airpower was again considered as the ideal tool for changing Milosevic's calculus. A Western ground component was excluded from the start because of the major political cleavages that might have caused the consensus in the Alliance to collapse. ${ }^{54}$

There is another reason for which Washington was not fond of the idea of a ground option:

[F]rom the air we had a thousand to one advantage on Milosevic. Once we got into those mountains of Yugoslavia where the Germans had been savaged - we were on the ground - our advantage was no longer a thousand to one. Maybe it was two to one. It would have been a daunting prospect to go over the Albanian Alps and send a land force into Belgrade ... Once the Serbs got us on the ground, the possibility

51 Byman, Daniel L. and Matthew C. Waxman (2008) 'Kosovo and the Great Air Power Debate', in Thomas G. Mahnken and Joseph A. Maiolo (eds) Strategic Studies: A Reader, London: Routledge, pp. 169-70.

52 Kagan, Frederick W. (2006) Finding the Target: The Transformation of American Military Policy, New York: Encounter Books, p. 187.

53 Lake, Anthony (2000) Six Nightmares, New York: Hachette Book Group, p. 81.

54 Daalder, Ivo H. (1999), 'U.S. Diplomacy before the Kosovo War', Brookings Institution, 28 September. Available at: www.brookings.edu/research/testimony/1999/09/28balkans-daalder. 
for guerrilla attacks, insurgency, there were all these tunnels that had been dug in World War II to protect against invasion. It would have been a bloody mess. ${ }^{55}$

But this gave Milosevic a certain window of opportunity to try to divide the Alliance and force the West to accept a different reality on the ground - a new ethnic balance. It followed a highly incremental, low-intensity, politically micro-managed military campaign, 'one that began small, the antithesis of Colin Powell's insistence on overwhelming force'. ${ }^{56}$ The focus was very much on the centres of gravity highlighted by John Warden, but in reverse priority, starting with 'the outermost ring and gradually worked into the inner rings - critical infrastructure, command and control nodes, and finally, just at the end of the campaign, the leadership itself ${ }^{\prime}{ }^{57}$ A fierce debate started between General Wesley Clark (at the time NATO's Supreme Allied Commander Europe) and Lt. Gen. Michael Short (at the time in charge of directing the air operations against Serbia). Clark wanted the airpower to be used primarily against the Serbian forces (tanks and irregular light units) operating in Kosovo against the Albanian local population, while for Short 'the jewel in the crown' was represented by the high-impact, but politically sensitive targets in downtown Belgrade. ${ }^{58}$ Gradually the campaign evolved closer to hitting the regime as the factories of Milosevic's cronies. ${ }^{59}$ It was not until Milosevic understood, however, that NATO had the political resolve to wage a ground campaign that he finally capitulated. ${ }^{60}$ Blair and Clinton were publicly talking about all options being on the table. There was a larger, highly visible, choreographic effort designed to persuade Milosevic that the Alliance was dead serious: elements of the 82nd Airborne Division were deployed in the region while 25,000

55 Interview with Samuel R. Berger (2005) Miller Center, University of Virginia. Available at: millercenter.org/oralhistory/interview/samuel-r-berger.

56 Priest, Dana (2004) The Mission: Waging War and Keeping Peace with America's Military, New York: W.W. Norton \& Company, p. 258.

57 Kagan, Frederick W. (2006) Finding the Target: The Transformation of American Military Policy, New York: Encounter Books, p. 191.

58 Priest, Dana (2004) The Mission: Waging War and Keeping Peace with America's Military, New York: W.W. Norton \& Company, pp. 264-5.

59 Interview with Samuel R. Berger (2005) Miller Center, University of Virginia. Available at: millercenter.org/oralhistory/interview/samuel-r-berger.

60 Daalder, Ivo H. and I. M. Destler (2009) In the Shadow of the Oval Office: Profiles of the National Security Advisers and the Presidents they Served: From JFK to George W. Bush, New York: Simon \& Schuster, p. 243. 
NATO troops were dispatched in Albania and Macedonia. ${ }^{61}$ Still, the Kosovo air campaign was an ugly victory (as Ivo Daalder and Michael $\mathrm{O}^{\prime}$ Hanlon would say at the time): 78 days of targeting; 26,600 bombs and missiles; 10,000 Kosovar Albanians killed; and more than 863,000 civilians leaving Kosovo during the campaign. ${ }^{62}$ The larger lesson to be taken at a time when Washington seemed to be again seduced by its promises might be that airpower should always be used in synergy with other instruments of power, because in Kosovo 'the air campaign by itself had not achieved the desired political and military ends, and that the determination to fight an air-only campaign rendered air power itself significantly less effective' ${ }^{63}$

In retrospect, the legacy of the Clinton interventionism - Haiti, Bosnia, Iraq, Kosovo - was about establishing a new playbook, rewriting the old rules of the road, and pushing for redefining the rights and obligations of state sovereignty - the building block of the international order. 'Nobody gave us a book when we came in. The old way clearly wasn't working. The world had fundamentally changed. The way you do business has to change, but how you do it took a while', reflected Nancy Soderberg, Deputy Assistant to the President for National Security Affairs. ${ }^{64}$ It was an imperative for a world where the main threats to international peace and security were generated from within states, by governments that were knocking out their own people. Figuring out and implementing the new rules was a messy process, but ultimately 'he brilliantly moved the United States from the Cold War into the post-Cold War, or 21st-century era' ${ }^{65}$ By 1999 , the nature of conversation was fundamentally changed. There was an increasing emphasis on a doctrine of international community. British Prime Minister Tony Blair captured the new zeitgeist:

61 Byman, Daniel L. and Matthew C. Waxman (2008) 'Kosovo and the Great Air Power Debate', in Thomas G. Mahnken and Joseph A. Maiolo (eds) Strategic Studies: A Reader, London: Routledge, p. 167.

62 Priest, Dana (2004) The Mission: Waging War and Keeping Peace with America's Military, New York: W.W. Norton \& Company, p. 266.

63 Kagan, Frederick W. (2006) Finding the Target: The Transformation of American Military Policy, New York: Encounter Books, p. 194.

64 Interview with Nancy Soderberg (2007) Miller Center, University of Virginia. Available at: millercenter.org/oralhistory/interview/nancy-soderberg.

65 Ibid. 
The most pressing foreign policy problem we face is to identify the circumstances in which we should get actively involved in other people's conflicts. Non-interference has long been considered an important principle of international order ... But the principle of noninterference must be qualified in important respects. Acts of genocide can never be a purely internal matter. ${ }^{66}$

This is the spirit that harnessed what was later codified as the Responsibility to Protect (R2P) norm - when national governments fail in their fundamental duty to protect their own citizens or are the perpetrators of large scale killing against them, it is the right of international community to intervene in order to substitute this responsibility ${ }^{67}$ — which, years later, was instrumental in preparing the ground for the NATO intervention in Libya in 2011.

The campaigns against Iraq during the 1990s can also be understood through the framework of R2P. Saddam Hussein never stopped being a focus for the Clinton Administration, but was mainly perceived as a containable threat to its own citizens in the south (the Shia population) and in the north (the Kurds). It is in this context that the Clinton administration contemplated military action against him only to uphold the no-fly zones and to contain his ambition to build weapons of mass destruction' ${ }^{68}$ The No Fly Zones (NFZs) were a reflection of the belief that sovereignty didn't provide local leaders a blank check to use force against their own people. Overall, the NFZs established in Iraq were highly successful in keeping Iraqi airpower outside the northern and southern parts of the country, but were much less successful in deterring ground troops from attacking the Shia and Kurd populations. ${ }^{69}$

During the 1990s, global terrorism was on the rise. The plot to destroy the World Trade Center (February 1993) and the attacks against US embassies in Kenya and Tanzania (August 1998) reflected the new trend. Bin Laden himself became a target for the US Government,

66 PBS Newshour (1999) 'The Blair Doctrine', 22 April. Available at: www.pbs.org/newshour/ bb/international-jan-june99-blair_doctrine4-23/.

67 Rice, Susan E. and Andrew J. Loomis (2007) 'The Evolution of Humanitarian Intervention and the Responsibility to Protect', in Ivo Daalder (ed.) Beyond Preemption: Force and Legitimacy in a Changing World, Washington DC: Brookings Institution Press, p. 83.

68 Chollet, Derek and James Goldgeier (2008) America Between the Wars: From 11/9 to 9/11, New York: Public Affairs, p. 206.

69 Zenko, Micah (2010) Between Threats and War: U.S. Discrete Military Operations in the PostCold War World, Stanford: Stanford University Press, p. 29. 
but, absent a 9/11 provocation, nobody was willing to use force on an extensive scale against Afghanistan as the state that presumably hosted him. Even the offshore strikes against the terrorist training camps were criticised on the Hill. However, at the end of Clinton Administration, Sandy Berger warned Rice: 'You're going to spend more time during your four years on terrorism generally and al-Qaeda specifically than any other issue. ${ }^{.70}$

The interventions in Bosnia, Haiti, Somalia, Iraq, and Kosovo were also instrumental in clarifying 'a new understanding of America's place in the world' ${ }^{71}$ For Albright and Holbrooke, the crises of the post-Cold War world showed the need for decisive US leadership, and prepared the ground for affirming America as an indispensable power in managing the most pressing threats to international peace and security:

The world's richest nation, one that presumes to great moral authority, cannot simply make worthy appeals to conscience and call on others to carry the burden. The world will look to Washington for more than rhetoric the next time we face a challenge to peace. ${ }^{72}$

\section{From Containment to Enlargement}

None of the military interventions launched by the Clinton Administration during the 1990s has any meaning outside of the enlargement framework that, in the end, captures the essence of his terms. In a way, this can be seen as a larger effort of the first truly postCold War presidency to shape the new era and articulate a coherent vision of the role of America in a new world. ${ }^{73}$ From its early days, the Clinton Administration made a constant, conscious search for developing a substitute to the containment doctrine that provided a clear-cut strategic rationale for the cold War. The White House

70 Daalder, Ivo H. and I. M. Destler (2009) In the Shadow of the Oval Office: Profiles of the National Security Advisers and the Presidents they Served: From JFK to George W. Bush, New York: Simon \& Schuster, p. 248.

71 Chollet, Derek and James Goldgeier (2008) America Between the Wars: From 11/9 to 9/11, New York: Public Affairs, p. 206.

72 Zenko, Micah (2010) Between Threats and War: U.S. Discrete Military Operations in the PostCold War World, Stanford: Stanford University Press, p. 29.

73 Chollet, Derek and James Goldgeier (2008) America Between the Wars: From 11/9 to 9/11, New York: Public Affairs, p. 65-6. 
needed to come up with a new grand strategy construct, as well as a core organising principle, able to set the direction for the US postCold War foreign policy. It is in this context that, in September 1993, Anthony Lake, the Assistant to the President for National Security Affairs, proposed a new guiding principle:

Throughout the Cold War, we contained a global threat to market democracies; now we should seek to enlarge their reach, particularly in places of special significance to us. The successor to a doctrine of containment must be a strategy of enlargement - enlargement of the world's free community of market democracies. ${ }^{74}$

An important emphasis here was on providing the institutional regional framework that was able to stabilise, encourage, and consolidate new democracies in key regions. In part, this is the role that NATO played in Central and Eastern Europe (CEE) over the last 20 years. In this interpretation, NATO is much more than a traditional political and military alliance or standard collective defence organisation. That is certainly at its core, but deeply embedded in its historical DNA is a transformative power: 'Even as NATO held the line against the Soviet Army, it drew France and Germany together. It helped integrate Italy and, eventually Spain, into the community of democracies. It gave shattered economies the confidence to recover. ${ }^{75}$ Specifically, in the former Warsaw Pact countries, by incentivising the reforming of military establishments, the restructuring of civil-military relations and playing the role of 'a magnet to build their democracies, settle their border disputes and deal with their minorities issues in an appropriate way' ${ }^{76}$ NATO would secure the domestic transitions ${ }^{77}$ under way in a highly sensitive region. The CEE countries were disposed in the near proximity of the Balkans, which at the time were massively ravaged by ethnic wars. The danger of spilling over was very real, especially in countries such as Romania and Hungary, where nationalistic impulses and zero-sum optics flooded the public space. It was in this sense that

\footnotetext{
74 Remarks of Anthony Lake, Assistant to the President for National Security Affairs, 'From Containment to Enlargement', Johns Hopkins University, School of Advanced International Studies, Washington DC, 21 September 1993.

75 Remarks of James B. Steinberg, Director, Policy Planning Staff, US Department of State, 'Advancing NATO's Adaptation', Atlantic Council of the United States, 13 June 1996.

76 Interview with Samuel R. Berger (2005) Miller Center, University of Virginia. Available at: millercenter.org/oralhistory/interview/samuel-r-berger.

77 Ikenberry, G. John (2001) After Victory: Institutions, Strategic Restraint and the Rebuilding of Order After Major Wars, Princeton: Princeton University Press, pp. 236-7.
} 
NATO enlargement acted as an engine for change by transforming societal impulses and empowering the reformist forces. Ultimately, the NATO expansion secured those countries and incentivised them to fix some of those structural weaknesses that plagued the former communist countries and were instrumental in the collapse of former Yugoslavia. Over time, the success of NATO enlargement prepared the ground for the EU expansion. In the end, the Clintonian enlargement framework reflected the spirit of the order - building projects designed to stabilise post- 1945 international relations. ${ }^{78}$ It was a way to tame the ghosts of the past, the legacies of 'unresolved and often conflicting historical resentments, ambitions, and, most dangerous, territorial and ethnic disputes', but at the same time spread the seeds of transformative forces, without which 'these lands remain vulnerable to the same problems, often exacerbated by an obsession with righting historical wrongs, real or mythical'.$^{79}$

It was debates over the Balkan wars that marked John Nagl's return to Oxford to study again under Professor O'Neill in 1995. Having served in a cavalry squadron that led the eventual American intervention, Nagl was keenly aware of the debates enumerated here, and cognisant of the lessons $\mathrm{O}^{\prime} \mathrm{Neill}$ taught from his own experience as a young army officer in Vietnam. It was the combination of $\mathrm{O}^{\prime}$ Neill's combat experience in that war and Nagl's own in Operation Desert Storm that convinced Nagl, with $\mathrm{O}^{\prime} \mathrm{Neill's}$ support and advice, that counterinsurgency would soon return to the forefront of strategic thought. That led to the writing of a doctoral dissertation that would eventually be published as Learning to Eat Soup with a Knife: Counterinsurgency Lessons from Malaya and Vietnam. ${ }^{80}$

Redefining the role of NATO for a post-Cold War world has a second dimension that was very much at the core of the debates inside the Clinton Administration. From its early days, NATO was the main instrument designed to contain and deter Soviet power in Europe. ${ }^{81}$ But in a world defined less by traditional aggression and more by the

78 Ikenberry, G. John (2001) 'What would a New Transatlantic Bargain Look Like?', in Mark D. Ducasse (ed.) The Transatlantic Bargain, Rome: NATO Defense College, p. 83.

79 Chollet, Derek and Samantha Powers (eds) (2011) The Unquiet American: Richard Holbrooke in the World, Philadelphia: Public Affairs, p. 179.

80 Nagl, John (2005) Learning to Eat Soup with a Knife: Counterinsurgency Lessons from Malaya and Vietnam, Chicago: Chicago University Press.

81 Ibid. 
'adverse consequences of instabilities that may arise from the serious economic, social and political difficulties, including ethnic rivalries and territorial disputes', ${ }^{82}$ NATO had to respond to new market niches, to the out of area instabilities that threatened European security. It was in this context that 'the purpose of NATO was being defined in Bosnia and in Kosovo' ${ }^{83}$ It was no longer about containing Russian power, but about crisis management in an unstable neighbourhood. In a way, NATO was still in the business of containment, but the enemy was not related to states that were too strong, but the chaos generated by states that were too weak. ${ }^{84}$ In short NATO had to adapt to an environment where 'local conflicts, internal political and economic instability, and the return of historical grievances have now replaced Soviet expansionism as the greatest threat to peace in Europe' ${ }^{85}$ The new profile that NATO adopted in the 1990s is very close to what Professor Robert O'Neill was proposing at the time, an Alliance for Development ${ }^{86}$ able to respond and remedy to the entrenched maladministration and pervasive weakness of the states in the land between Western Europe and Russia. He understood immediately the need to go beyond the core traditional military competencies that were part of the NATO traditional brand. Ultimately, the whole NATO adaptation reflected the spirit of the Alliance for Development because the entire process 'aimed at the long-term building of secure, prosperous states which ultimately can either take their place as members of the EU, or enter into long, close and peaceful association with it'. ${ }^{87}$

But the post-Cold War NATO transformation was not without controversy. George Kennan was one of the most visceral critics of that decision. He considered the NATO enlargement as 'the most fateful

\footnotetext{
82 NATO (1991) 'The Alliance's New Strategic Concept'. Available at: www.nato.int/cps/en/ natolive/official_texts_23847.htm.

83 Interview with Samuel R. Berger (2005) Miller Center, University of Virginia. Available at: millercenter.org/oralhistory/interview/samuel-r-berger.

84 Nagl, John (2014) Knife Fights: A Memoir of Modern War in Theory and Practice, New York: Penguin Books, pp. 237-8.

85 Chollet, Derek and Samantha Powers (eds) (2011) The Unquiet American: Richard Holbrooke in the World, Philadelphia: Public Affairs, p. 176.

86 O'Neill, Robert (1998) 'Europe and the Wider World: The Security Challenge', in Ken Booth (ed.) Statecraft And Security. The Cold War and Beyond, New York: Cambridge University Press, p. 207.

87 Ibid., p. 206.
} 
error of American policy in the entire post-cold-war era', ${ }^{88}$ a tragic mistake that would humiliate and alienate Russia and empower the anti-reformist nationalist elites. After the Crimea annexation, that entire revisionist school was resurrected. They vindicate Kennan's insight considering NATO expansion as 'a bad idea with predictable bad results', ${ }^{89}$ a punitive peace that exploited Russian disarray and one that Moscow had little choice but to swallow. But imagine how the CEE region would have looked in the absence of a NATO enlargement to the east. It would have been a gigantic Ukraine-like grey zone, a ring of hollow states with very weak, corrupted structures ripe for insidious subversion and intimidation in the proximity of the Russian Empire. In short, it would have provided the perfect target, the ideal playground for hybrid warfare. As Robert Kaplan pointed out recently, 'what the Putin regime likes the most is weak democracies'. ${ }^{90}$ These provide the right societal foundation for orchestrating all kinds of intelligence operations, for subversion, for corruption, for buying off politicians and influence. Seen in retrospect, NATO was responsible for clearing and holding the former Warsaw Pact countries by keeping them outside of the Russian influence, while in the successive stages, the EU was responsible for building European modernised countries.

\section{Lessons in Post-Cold War Interventionism: The 1990s as a Preview of the Post-9/11 COIN Era}

Nobody described better the relevance of the 1990s for the type of campaigns that shaped the post-9/11 security environment than US Secretary of Defense Robert Gates. In a 2007 speech, he emphasised that, after Vietnam,

the Army relegated unconventional war to the margins of training, doctrine, and budget priorities ... This approach may have seemed validated by ultimate victory in the Cold War and the triumph of Desert Storm. But it left the service unprepared to deal with the

\footnotetext{
88 Kennan, George F. (1997) 'A Fateful Error', The New York Times, 5 February.

89 Bremmer, Ian (2015) Superpower: Three Choices for America's Role in the World, Great Britain: Portfolio Penguin, p. 14.

90 Kaplan, Robert D. (2015) 'The Future of Geopolitics in the Lands Between Baltic and Black Seas', keynote speech presented to CEPA Forum, Washington DC, 2 October.
} 
operations that followed: Somalia, Haiti, the Balkans, and more recently Afghanistan and Iraq - the consequences and costs of which we are still struggling with today. ${ }^{91}$

The last decade of the twentieth century reflects a perpetual clash between the guardians of the traditional American way of war as the antithesis of Vietnam (one focused on 'a strategy of annihilation' and obsessed by 'how to secure victory in its desired fullness ${ }^{\prime 2}$ ) and a different generation who understood that Desert Storm was not the return of the old days, of 'good, clean soldiering' in the spirit of the Second World War, but an aberration and 'the final salute of the Cold War military'. ${ }^{93}$ It was just a preview of a new age, where campaigning was messy and slow, like eating soup with a knife, and where the core mission was less about destroying armies and more about helping to rebuild nations and societies.

Most of the 1990s interventions (Somalia in particular, but including Haiti, Bosnia and Kosovo) should have forced America to rethink the definition of what success means in the context of the post-Cold War battlefields. Winning in the so-called MOOTWs (Military Operations Other Than War) was no longer about military success in itself, but about the ability to focus on the societal dimensions of warfare, local dynamics, and political vacuums. General Rupert Smith, a veteran of the Balkans, emphasised that the hallmark of the post-Cold War interventionism was about establishing 'a condition in which the political objective can be achieved by other means and in other ways' ${ }^{94}$ Over time, everything came to depend 'on progress on local parties' political steps, not on a superpower's military prowess' ${ }^{95}$ By themselves, military means were hardly enough. They could secure the environment and provide a 'breathing space', but

91 Small Wars Journal Editors (2007) 'SECDEF Robert Gates, 10 Oct 07 AUSA Speech', Small Wars Journal. Available at: smallwarsjournal.com/blog/secdef-robert-gates-10-oct-07ausa-speech.

92 Weigley, Russell F. (1973) The American Way of War: A History of United States Military Strategy and Policy, New York: Macmillan, p. 22.

93 Clancy, Tom with General Tony Zinni (Ret.) and Tony Koltz, Battle Ready, New York: Berkley Books, p. 488.

94 Smith, Rupert (2006) The Utility of Force: The Art of War in the Modern World, London: Penguin Books, p. 270.

95 Soderberg, Nancy (2005) The Superpower Myth: The Use And Misuse of American Might, New Jersey: John Wiley \& Sons, p. 36. 
the military mission on its own, will not achieve a strategic objective ... The goal should be broader: the future of society itself. In a strategic sense, a peacekeeping operation is more about political progress and economic programs than it is about troops in blue berets. ${ }^{96}$

As a consequence, the expectations for fast exit strategies should have been changed as the 1990s interventionism revealed 'the international forces must remain in place, not only until military tasks are completed but also until the indigenous political will and structures exist to support a stable government and a local security force to keep the peace' ${ }^{97}$

Haiti perfectly illustrates this point. The Clinton Administration 'prematurely declared that our mission had been accomplished' ${ }^{98}$ For the White House, the return of Jean Bertrand Arstide, the legitimate elected leader, was considered the end of the process, when in fact it should have been another intermediate step towards building 'a normal country, capable of fending for itself and governing itself decently' ${ }^{99}$ But without a significant US presence on the ground for the long haul, to shape the environment, incentivise and pressure the necessary reforms, the country 'slipped back into civil unrest and corrupt, incompetent, often violent politics' ${ }^{\prime}{ }^{100}$ For some of the decision-makers at the time, the lesson was clear: 'The Clinton Administration should not have left Haiti to its own devices and its deeply flawed leadership, thereby allowing an initial success to turn into failure.' ${ }^{101}$ This would become a familiar snapshot for the counterinsurgents of the post-9/11 era. Stability operations are not just about building strong host nation institutional capacities, but also legitimacy and good governance. Time and time again, whether in Kosovo, Afghanistan, or the post-surge Iraq, the host nation leadership will choose to behave as a predatory government, operating 'as a collection of patronage networks that systematically extract resources from the population for the benefit of those networks and the power brokers who run them'. ${ }^{102}$ Tony Lake

\footnotetext{
96 Lake, Anthony (2000) Six Nightmares, New York: Hachette Book Group, p. 193.

97 Ibid., p. 94.

98 Talbott, Strobe (2008) The Great Experiment: The Story of Ancient Empires, Modern States, and the Quest for a Global Nation, New York: Simon \& Schuster, p. 302.

99 Ibid., p. 303.

100 Ibid.

101 Ibid.

102 Biddle, Stephen (2014) 'Afghanistan's Legacy: Emerging Lessons of an Ongoing War', The Washington Quarterly 37(2), p. 80.
} 
summarised his take away from Haiti as: 'we were to see how much easier it is to help a nation build the structures of democracy than it is to change a political culture. ${ }^{103}$

The 1990s operations also reflected the need to change the roles and missions the militaries were expected to perform. At their core, they remained fighting machines along the lines of the traditional American way of war, but in addition there was an entire new spectrum of responsibilities, most of them 'much more intrinsically political in nature'. ${ }^{104}$ As one of the officers formed during postCold War operations, Tony Zinni discovered that on the MOOTW battlefields of the 1990s, he had to deal with 'political problems, with humanitarian problems, with economic reconstruction, with social problems' ${ }^{105}$ In Somalia, he served on 'the political, security, judicial and police committees ... met with women's groups, schoolteachers' and other professional groups, to hear complaints and get cooperation for projects', ${ }^{106}$ and he coordinated extensive psyops, civic action, and rebuilding projects. And all these from an officer that came from a military that regarded the Second World War as 'the last Good War the last with moral clarity, an easily identified and demonized enemy, unprecedented national unity ... World War Two was the way you fight a war. ${ }^{107}$ It was his generation's legacy, a tradition he was taught that must be preserved. It was also the kind of 'clear-war fighting mission' that the military was comfortable with and constantly searching for. Nothing prepared him for the ubiquitous rebuilding and reconstruction tasks in a world where peacekeeping, peace enforcement and 'vague, confusing military actions heavily overlaid with political, humanitarian and economic considerations' defined the new normal. ${ }^{108}$

103 Lake, Anthony (2000) Six Nightmares, New York: Hachette Book Group, p. 140.

104 O'Neill, Robert (1997) 'The Remaking of Modern Armies Post Cold War', in Peter Dennis and Grey Jeffrey (eds) The Second Fifty Years: The Australian Army 1947-1997, Canberra: ADFA, p. 4.

105 Remarks by General Anthony C. Zinni (2004) 'From the Battlefield to the Negotiating Table: Preventing Deadly Conflict', Joan B. Kroc Distinguished Lecture Series, University of San Diego, 15 April.

106 Clancy, Tom with General Tony Zinni (Ret.) and Tony Koltz, Battle Ready, New York: Berkley Books, p. 299.

107 Ibid., p. 483.

108 Ibid., p. 498. 
There is another key component emphasised by the MOOTW battlefields that will become a common denominator in every post9/11 stability operation - the imperative to devise a comprehensive approach that will blend and synchronise civil and military efforts in recognition of the fact that the military tools are barely enough. Analysing the 1990s, Professor Robert O'Neill clearly understood that the new security environment called for comprehensive skills 'on a wide series of fronts, civil and military', ${ }^{109}$ bringing together specific expertise in democratic practice, law, local government, public health, communal relations, religious affairs, urban development, economics and business development, policing and military affairs. ${ }^{110}$ At the same time, stabilising a country required strategic patience for the long haul, being able to plan, correlate sequences and manage broadly 'on several time scales - the long term for economic and social development, the mid term for military force development and political reforms, and the short term for peacekeeping, conflict resolution or peace enforcement'. ${ }^{111}$ For a counterinsurgent of the 1960s, 1970s, or from the post-9/11 era, this would be simply déjà vu. He would have understood instantly the primacy of political and administrative aspects, but also the need for an integrated civil-military framework that ties together the different lines of operations 'diplomacy, information operations, intelligence, financial and military — to achieve predominantly political objectives'. ${ }^{112}$ The problem is that, in reality, that degree of cohesiveness between very different civilian and military cultures is very hard to develop in theatre. In Bosnia, for example, there was never a coordinating whole of government machinery 'that brought the civilian, nongovernmental and military resources of the United States and Europe together' to force change. ${ }^{113}$

109 O'Neill, Robert (1998) 'Europe and the Wider World: The Security Challenge', in Ken Booth (ed.) Statecraft And Security. The Cold War and Beyond, New York: Cambridge University Press, p. 200.

110 Ibid., p. 201.

111 Ibid., p. 207.

112 Nagl, John (2005) Learning to Eat Soup with a Knife: Counterinsurgency Lessons from Malaya and Vietnam, Chicago: Chicago University Press, p. 16.

113 Priest, Dana (2004) The Mission: Waging War and Keeping Peace with America's Military, New York: W.W. Norton \& Company, p. 256. 
Nonetheless, most of the MOOTWs of the 1990s provided formative experiences for an entire generation of officers, immersing them in new operational challenges beyond the type to which they were accustomed. These challenges proved to be the ultimate harbingers of things to come at a highly different intensity, complexity, and scale after 9/11. In fact, the generation that would later serve in Afghanistan and Iraq 'cut their teeth on a decade of other than war missions'. ${ }^{114}$ For Lieutenant Colonel David Petraeus, the Operations Chief for the UN force in Haiti, it was an opportunity to learn

what nation building is all about: nation building was very prominent there, and here is where I got my first experience, actually truly conducting a complete comprehensive civil-military campaign: train their police units, reform the penitentiary system which was a disaster at the time, rebuild rule of law, re-establish basic services (electricity, food, shelter, water) in a country that was at the basic level of public services imaginable. ${ }^{115}$

The American troops dispatched in Kosovo as peacekeepers under the NATO umbrella soon discovered the contours of what Dana Priest described as an enduring invisible battlefield, an underground world of parallel structures and shadowy governance networks - like the Ministry of Public Order - controlled by former Kosovo Liberation Army (KLA) separatists and their Mafia-like organisations ${ }^{116}$ that 'intimidated, threatened, assaulted and sometimes allegedly killed anyone who questioned their rule' ${ }^{117}$ It is here in the microcosm of Kosovo that the American troops were exposed to the need to protect the local communities and population. In the mixed town of Vitina, 'they escorted every day Serb children to school, and every week they took families to Serbia proper or Macedonia to shop or visit relatives'. ${ }^{118}$ It is in the Balkans that American troops had to build relations amongst the people, with the local church and shopkeepers, understand the puzzle of local grievances, loyalties, and family

114 Davidson, Janine (2010) Lifting the Fog of Peace: How Americans Learned to Fight Modern War, Ann Arbor: University of Michigan Press, p. 95.

115 Manea, Octavian (2013) 'Reflections on the 'Counterinsurgency Decade': Small Wars Journal Interview with General David H. Petraeus', Small Worlds Journal. Available at: smallwarsjournal. $\mathrm{com} / \mathrm{jrnl} / \mathrm{art} / \mathrm{reflections-on-the-counterinsurgency-decade-small-wars-journal-interview-with-}$ general-david.

116 Priest, Dana (2004) The Mission: Waging War and Keeping Peace with America's Military, New York: W.W. Norton \& Company, p. 271.

117 Ibid., p. 309.

118 Ibid., p. 317. 
connections, while mediating and managing deep communal tensions between angry ethnic communities in town hall meetings. ${ }^{119}$ As the post-9/11 veterans would soon discover:

You win these kinds of wars by drinking tea, lots of tea. Ultimately, to earn the support of the population, you have to gain their trust and the way you gain their trust is by developing personal relationships. You must be more than a uniform and it is important for the leaders to take their helmets off, take their protective glasses off, body armor off and demonstrate that they trust people whose support they are trying to earn. ${ }^{120}$

Often the top US officer in charge of Vitina had to be 'mayor, police chief, judge and jury'. ${ }^{121}$ Kosovo was where the American troops had to understand and navigate very detailed, grass-root, connect-thedots linkages across the human terrain, especially the underground administrative hierarchy, in order to dismantle the real spoilers of local peace and stability. But this required a different set of skills that were closer to 'old fashioned detective work'.${ }^{122}$ Most of these snapshots will be familiar to any veteran of the post-9/11 stability operations or to any student of counter-insurgency. For example, fighting in Khalidiyah, a town lost in the Sunni triangle, was more 'akin to breaking up a Mafia crime ring than dismantling a conventional enemy battalion or brigade' ${ }^{123}$ Be it Talibans, Al-Qaeda in Iraq, Vietcong, or the subversive underground networks of former KLA fighters, they all understood that first and foremost they are in a competition for governance, and what they had to do was to establish 'a competitive system of control over population'. In the end 'when a country is being subverted it is not being outfought; it is being out-administered'. ${ }^{124}$

119 Ibid., p. 315.

120 Manea, Octavian (2010) 'Interview with Dr. John Nagl', Small Wars Journal. Available at: smallwarsjournal.com/jrnl/art/interview-with-dr-john-nagl.

121 Priest, Dana (2004) The Mission: Waging War and Keeping Peace with America's Military, New York: W.W. Norton \& Company, p. 315.

122 Ibid., p. 309.

123 Nagl, John (2005) Learning to Eat Soup with a Knife: Counterinsurgency Lessons from Malaya and Vietnam, Chicago: Chicago University Press, p. 13.

124 Fall, Bernard B. (1998) 'The Theory and Practice of Insurgency and Counterinsurgency', Naval War College Review, Winter. Available at: www.au.af.mil/au/awc/awcgate/navy/art5-w98. htm\#rettop. 
Overall, the lessons of the last decade of the twentieth century suggest, as Robert $\mathrm{O}^{\prime} \mathrm{Neill}$ anticipated, that the imperative - in public policy circles, armed services, think tank community, and media - was to develop 'a new science of security which fits the new era, in much the same way that military strategy of the pre-nuclear era had to adapt to the Cold War' ${ }^{125}$

125 O'Neill, Robert (1998) 'Europe and the Wider World: The Security Challenge', in Ken Booth (ed.) Statecraft And Security. The Cold War and Beyond, New York: Cambridge University Press, p. 207. 
This text is taken from War, Strategy and History: Essays in Honour of Professor Robert O'Neill, edited by Daniel Marston and Tamara Leahy, published 2016 by ANU Press, The Australian National University,

Canberra, Australia. 